\title{
Chemical components of essential oils and biological activities of the aqueous extract of Anethum graveolens L. grown under inorganic and organic conditions
}

\author{
Sedef Ozliman', Gulsum Yaldiz*, Mahmut Camlica ${ }^{1}$ and Nurten Ozsoy ${ }^{2}$
}

\begin{abstract}
Background: In sustainable agriculture, the use of farmyard manure (FYM) is of great interest to environmental security and is effective as a good nitrogen source for sustainable crop production. Therefore, determining the effective doses of FYM that will be an alternative to chemical fertilizers, is also important to improve soil fertility and produce healthy products. This study aimed to determine the effects of FYM and ammonium nitrate (AN) fertilizers on the biological value and essential oil content of dill (Anethum graveolens L.).
\end{abstract}

Methods: Different doses FYM (7.5, 10, 12.5 and $\left.15 \mathrm{t} \mathrm{ha}^{-1}\right)$ and AN (30, 60, 90 and $\left.120 \mathrm{~kg} \mathrm{ha}^{-1}\right)$ were applied by sowing and compared to a control group (no manure). We evaluated the chemical constituents as well as the biological activities of dill herbs and seeds growing at various doses of FYM and AN fertilizers.

Results: The most abundant components of essential oils were found to be dill apiole (11.96 \pm 0.83 and $18.65 \pm 1.89 \%)$ and carvotanacetone (15.90 \pm 2.34 and $21.76 \pm 1.62 \%)$ in the leaves and seeds, respectively. Limonene ( $9.01 \pm 1.11 \%)$, 4-isopropyltoluen ( $8.24 \pm 0.89 \%)$, dill ether $(9.13 \pm 1.12 \%)$ and mycrene $(7.44 \pm 0.68 \%)$ were major essential oils components in herbs. The highest concentration of the essential oil components was determined as 12.5-15 t ha ${ }^{-1}$ in FYM and 90 AN applications. From the effective concentration ( $E C_{50}$ ) of the samples, it was seen that $60 \mathrm{~kg} \mathrm{ha}^{-1}$ AN infusion, $120 \mathrm{~kg} \mathrm{ha}^{-1}$ AN decoction as well as $7.5 \mathrm{t} \mathrm{ha}^{-1} \mathrm{FYM}$ and $10 \mathrm{t} \mathrm{ha}^{-1} \mathrm{FYM}$ essential oils had the highest DPPH, $\mathrm{ABTS}^{+}$and superoxide anion radical scavenging activity as shown by the lowest value of $\mathrm{EC}_{50}$ compared to the control. Although the antioxidant activities of the samples were significantly lower than those of the reference antioxidant gallic acid, it was evident that they did show the antioxidative potential for hydrogen and a single electron donor activities, thus could serve as free radical scavengers, and act as reductant. In particular, the highest total phenolic content $\left(18.36 \pm 0.35 \mathrm{mg} \mathrm{g}^{-1}\right)$ was found in the infusion extract after applying the $60 \mathrm{~kg} \mathrm{ha}^{-1}$ AN fertilizer. Essential oils extracted from the seeds also exhibited strong antibacterial activity against Staphylococcus epidermidis, Enterococcus faecalis, and Pseudomonas aeruginosa. The highest antibacterial activity against all tested microbial species was observed with the $10 \mathrm{t} \mathrm{ha}^{-1} \mathrm{FYM}$ application.

Conclusion: The findings of the study suggest that the application of FYM has promising effects on dill leaf, seed, and herb and can be considered as a suitable substitute for chemical fertilizers when growing dill, a plant with increasing importance and demand.

Keywords: Anethum graveolens, Aqueous extract, Biological activity, Essential oil, Farmyard manure

\footnotetext{
*Correspondence: g_yaldiz@hotmail.com

1 Department of Field Crops, Faculty of Agriculture, Bolu Abant Izzet

Baysal University, 14280 Bolu, Turkey

Full list of author information is available at the end of the article
} 


\section{Background}

Dill (Anethum graveolens L.) is an aromatic annual plant belonging to the Apiaceae family. It originates from Eastern Mediterranean. For many years, it has been used by boiling in water for the preparation of decoction or infusion to cure diseases [1].

Dill is frequently grown for flavoring and therapeutic features in various health problems, such as digestive disorders accompanied by meteorism, flatulence and gastro-intestinal spasms, urinary infections, insomnia, and galactogenicalhypo secretion. Seeds of dill are commonly utilized in food and pharmaceutical industries, as well as in traditional medicine to treat gastrointestinal problems and rheumatism [2].

The entire vegetative organ contains essence. Phellandrene, dill ether, carvone, limonene, apiol, dihydrocarvone, and myristicin are the major components of dill [3]. The plant contains phenolic acids and aromatic components; therefore, it has antioxidant, antimicrobial and antitumor activities [4]. The antioxidant activity mostly results from phenolic components and has significant roles in absorbing and deactivating free radicals, quenching singlet and triplet oxygen, or decomposing peroxides [5].

In sustainable agriculture, organic fertilizers not only supply plant nutrients but also improve soil organic matter content as a natural, renewable source [6]. Farmyard manure (FYM) is the most popular organic fertilizer maintaining soil fertility in alternative agriculture systems. FYM has a high proportion of organic material which nurtures soil organisms and is essential in maintaining an active soil life. The high organic matter content and active soil life improve or maintain friable soil structures, increase the cation exchange capacity, water holding capacity, and infiltration rate, and reduce the risk of soil pests building up [7]. In studies on FYM, to obtain high quality and yield, FYM is recommended to be used at a dose of $10 \mathrm{tha}^{-1}$ in palmarosa [8], $15 \mathrm{tha}^{-1}$ in lettuce [9], $15 \mathrm{t} \mathrm{ha}^{-1}$ in sweet potato [10], $11.5 \mathrm{t} \mathrm{ha}^{-1}$ in spider plant [11], and $10 \mathrm{t} \mathrm{ha}^{-1}$ in tomato [12]. Similarly, effective nitrogen doses were reported as $100 \mathrm{~kg} \mathrm{ha}^{-1}$ for sater [13], $90 \mathrm{~kg} \mathrm{ha}^{-1}$ for safflower [14], $120 \mathrm{~kg} \mathrm{ha}^{-1}$ for lemon balm [15], and $50 \mathrm{~kg} \mathrm{ha}^{-1}$ for sage [16].

Although it is known that alternative organic manures should be used instead of chemical fertilizers, there are insufficient studies on the effect of bio-fertilizers on the growth and yield of medicinal plants. While the chemical characters of dill have been evaluated in dill genotypes [17], such studies have not been conducted together with FYM in dill genotypes. Therefore, the current study can be accepted as the first extensive report to assess the effects of various rates of FYM and ammonium nitrate (AN) on total phenolic mater, antioxidant and antibacterial efficacy of essential oil, decoction and infusion extract of dill, and to identify the essential oil compounds contained in this plant. The purpose of this study was to determine the chemical constituents of dill herbs and seeds, as well as evaluate biological activity in samples grown using various doses of FYM and AN fertilizers.

\section{Materials and methods \\ Growing conditions and treatments}

The study was conducted in two successive years (2016 and 2017) at an experimental farm $\left(40^{\circ} 28^{\prime} 43^{\prime \prime} \mathrm{N}\right.$, $\left.31^{\circ} 12^{\prime} 39^{\prime \prime} \mathrm{E}\right)$ of Mudurnu Süreyya Astarcı Vocational High School (Bolu, Turkey). The elevation of the farm was approximately $830 \mathrm{~m}$. The experiment was planned in a randomized complete-block design with a splitplot arrangement with three replications in April 2016 and 2017 in open-field conditions. Farmyard manure (FYM) and Ammonium nitrate (AN) were placed in the main plot, and sub-plot was four levels of FYM applications $\left(7.5,10,12.5\right.$ and $\left.15 \mathrm{tha}^{-1}\right)$ and $\mathrm{AN}(30,60,90$ and $120 \mathrm{~kg} \mathrm{ha}^{-1}$ ) with a control (no fertilizer or manure).

Each experimental plot consisted of five rows, with a distance of $0.3 \mathrm{~m}$ between each row and $0.2 \mathrm{~m}$ between each plant, and the plot size was $5.6 \mathrm{~m}^{2}$. For the distance between the plots, a meter block was considered. The soil was rich in phosphorus $\left(14.86 \mathrm{~g} \mathrm{~kg}^{-1}\right)$, potassium $\left(53.73 \mathrm{~g} \mathrm{~kg}^{-1}\right)$ and organic matter $\left(13.6 \mathrm{~g} \mathrm{~kg}^{-1}\right)$, and classified as clay-loam and having neutral quality $(\mathrm{pH}=7.25)$. According to the climatic data, the average temperature, humidity, and total rainfall from April to August in the two experimental years were $8.18^{\circ} \mathrm{C}, 61 \%$, and $208.8 \mathrm{~mm}$, respectively [18].

FYM was composed of dung, urine, bedding and straw, and obtained from the rearing farm of a cattle or cow meat production facility in Bolu, Turkey. Dung mostly comes as undigested material and urine from digested material. Organic matter contents of dung are over 50\%, being as a complex of lignin and protein, which are difficult to decompose. For that reason, nutrients in dung are slowly released but nutrients in urine are easily available and obtainable. To alleviate the urine loss and therefore to increase manure volume, straw, sawdust or other bedding materials are used in cattle shelters [19]. Wet manure from the barn was spread on a flat soil area at a height of 40-60 cm and width of 1.5-2 $\mathrm{m}$, in the form of a trapezoid with a length permitted by the area. The manure from the barn, which was cleaned once a week, was laid in a series and transferred to the side every three days. It was well ventilated during this transfer, and this application was continued for $21 \mathrm{~d}$. The compost pit was protected from rain, and small drainage channels were formed to divert run-on water. At the end, the pile 
became odorless and black and white in color, with yellow worms being formed. This formation indicates that the manure was matured. Before application, FYM was stored for fermentation for about one year. Full dose of the FYM was applied to seedbeds and mixed with soil per treatment requirement. No inorganic fertilizer was applied to the FYM plots throughout the life of the plant. FYM properties used in experiment were provided in Table 1. FYM had the highest organic matter (406.8 $\mathrm{g} \mathrm{kg}^{-1}$ ), containing $18 \mathrm{~g} \mathrm{~kg}^{-1}$ nitrogen, $5.2 \mathrm{~g} \mathrm{~kg}^{-1}$ phosphorus, and $13.6 \mathrm{~g} \mathrm{~kg}^{-1}$ potassium, and it was slightly alkaline [20].

As experimental factors, different doses of FYM (7.5, $10,12.5$ and $15 \mathrm{t} \mathrm{ha}^{-1}$ ) were applied a week before sowing. For the subsurface application, the manure was mixed in at soil a depth of approximately $10 \mathrm{~cm}$ with a rotary tiller. Also, $300 \mathrm{~kg} \mathrm{ha}^{-1}$ diammonium phosphate (DAP) and half of 30, 60, 90 and $120 \mathrm{~kg} \mathrm{ha}^{-1} \mathrm{AN}$ (33\%) as base fertilizer were applied by sowing. The remaining half of the AN fertilizer was applied as top dressing after the first harvest. Dill was regularly watered with a drip irrigation system. No pesticide was used in this study. Dill harvest was performed at the beginning of flowering at noontime; then, the plant was dried in shade to prepare it for laboratory analyses.

Table 1 Chemical analysis of farmyard manure

\begin{tabular}{lll}
\hline Analysis parameters & Unit & $\begin{array}{l}\text { Results } \\
\text { of the } \\
\text { analysis }\end{array}$ \\
\hline Organic matter & $\mathrm{g} \mathrm{kg}^{-1}$ & 406.8 \\
Total nitrogen (N) & $\mathrm{g} \mathrm{kg}^{-1}$ & 18.00 \\
Moisture & $\mathrm{g} \mathrm{kg}^{-1}$ & 595.00 \\
pH (potentiometric) & - & 7.61 \\
EC (1/10) & $\mathrm{mS} \mathrm{cm}^{-1}$ & 3.26 \\
Total phosphorus (P) & $\mathrm{g} \mathrm{kg}^{-1}$ & 5.20 \\
Water soluble phosphorus (P2O5) & $\mathrm{g} \mathrm{kg}^{-1}$ & 3.20 \\
Total potassium (K) & $\mathrm{g} \mathrm{kg}^{-1}$ & 13.60 \\
Water soluble potassium (K ${ }_{2}$ O5) & $\mathrm{g} \mathrm{kg}^{-1}$ & 10.40 \\
Total calcium (Ca, ICP EPA 3052) & $\mathrm{g} \mathrm{kg}^{-1}$ & 7.758 \\
Total Magnesium (Mg, ICP EPA 3052) & $\mathrm{g} \mathrm{kg}^{-1}$ & 5.099 \\
Total iron (Fe, ICP EPA 3052) & $\mathrm{g} \mathrm{kg}^{-1}$ & 10.606 \\
Total copper (Cu, ICP EPA 3052) & $\mathrm{g} \mathrm{kg}^{-1}$ & 0.025 \\
Total zinc (Zn, ICP EPA 3052) & $\mathrm{g} \mathrm{kg}^{-1}$ & 0.09 \\
Total manganese (Mn, ICP EPA 3052) & $\mathrm{g} \mathrm{kg}^{-1}$ & 0.37 \\
Total lead (Pb, ICP EPA 3052) & $\mathrm{g} \mathrm{kg}^{-1}$ & 0.002 \\
Total cadmium (Cd, ICP EPA 3052) & $\mathrm{g} \mathrm{kg}^{-1}$ & DLA \\
Total cobalt (Co, ICP EPA 3052) & $\mathrm{g} \mathrm{kg}^{-1}$ & DLA \\
\hline DLA dection Imits: Cd 0.0003 &
\end{tabular}

DLA detection limits: $\mathrm{Cd}<0.00003 \mathrm{~g} \mathrm{~kg}^{-1}$, Co $<0.00008 \mathrm{~g} \mathrm{~kg}^{-1}$ $\mathrm{Pb}<0.00009 \mathrm{~g} \mathrm{~kg}^{-1}$

\section{Preparation of sample solution}

To prepare infusions, each sample (5 g) was added to $25 \mathrm{~mL}$ of boiling distilled water and left to stand at room temperature for $5 \mathrm{~min}$, and then filtered through Whatman No. 4 paper. To prepare decoctions, each sample $(5 \mathrm{~g})$ was added to $25 \mathrm{~mL}$ of distilled water, heated on a heating plate (VELP Scientific, Usmate, Italy) and boiled for $30 \mathrm{~min}$. The mixture was left to stand at room temperature for $5 \mathrm{~min}$ more, and then filtered through Whatman No. 4 paper, and the extracts were kept at $-80{ }^{\circ} \mathrm{C}$ for 1 night and lyophilized (Free Zone 4.5, Labconco, Kansas City, MO, USA) for a minimum of $4 \mathrm{~h}$. The extracts taken into bottles were kept in the refrigerator until the activity study was performed. The biological activities were evaluated directly on the decoctions/infusions [21].

To prepare essential oils, approximately $30 \mathrm{~g}$ dried herbs, leaves and seeds were used for the essential oil isolation in dill. Dried herbs, leaves and seeds were put into balloon using a clevenger apparatus with the TS8882 method throughout $3 \mathrm{~h}$. Anhydroussodium sulphate was used to obtained dry essential oil isolation and was kept at $4{ }^{\circ} \mathrm{C}$ until use. The yields of essential oil were calculated after dried weight of each sample.

\section{Gas chromatography-mass spectrometry/flame ionization detection (GC-MS/FID)}

Essential oil components were analyzed using an Agilent Technologies 7890A (Santa Clara, CA, USA) coupled with a flame ionization detection detector and mass spectrometry (model 5975C) and HP-Innowax capillary column $(60.0 \mathrm{~m} \times 0.25 \mathrm{~mm} \times 0.25 \mu \mathrm{m})$. Hexane was used for the essential oil components with dilution ratio 1:50. GC-MS/FID analysis was carried out using a split mode of 50:1. Injection volume and temperature were adjusted to $1 \mu \mathrm{L}$ and $250{ }^{\circ} \mathrm{C}$, respectively. Oven temperature gradually raised from $60{ }^{\circ} \mathrm{C}$ to $250{ }^{\circ} \mathrm{C}$ at $10{ }^{\circ} \mathrm{C} \mathrm{min}{ }^{-1}$, held for $20 \mathrm{~min}$ and then holding at $250^{\circ} \mathrm{C}$ for $8 \mathrm{~min}$. Helium (purity 99.9\%) was used the carrier gas at a flow rate of $1 \mathrm{~mL} \mathrm{~min}{ }^{-1}$. Mass scanning was from 35 to $450 \mathrm{amu}$, and the ionization mode used was electronic impact mode $(70 \mathrm{eV})$. The relative percentage of the components was calculated from GC-FID peak areas and components were identified using the WILEY, NIST and FLAVOR libraries [22].

\section{Determination of total phenolic compounds}

Total soluble phenolics in the infusion and decoction preparations from the dried herbs of dill were determined with Folin-Ciocalteu reagent according to the method of Slinkard and Singleton [23] with some modifications. Aliquots $(0.1 \mathrm{~mL})$ of extracts were put into the 
test tubes and their volumes made up to $4.6 \mathrm{~mL}$ using distilled water. Then, $0.1 \mathrm{~mL}$ Folin-Ciocalteu reagent (previously diluted threefold with distilled water) and $0.3 \mathrm{~mL}$ $2 \% \mathrm{Na}_{2} \mathrm{CO}_{3}$ solution were added and tubes were vortexed and absorbance of mixture was recorded after $2 \mathrm{~h}$ at $760 \mathrm{~nm}$ against a blank containing $0.1 \mathrm{~mL}$ of extraction solvent. Gallic acid $\left(0.05 \mathrm{mg} \mathrm{mL}^{-1}-0.4 \mathrm{mg} \mathrm{mL}^{-1}\right)$ was used for calibration of a standard curve. The results were expressed as gallic acid equivalents (GAE) $\mathrm{g}^{-1}$ of extract.

\section{Determination of the antioxidant potential through free radical DPPH}

The DPPH radical scavenging ability of the samples was assessed by the method described by Brand-Williams et al. [24]. A $0.1 \mathrm{~mL}$ extract aliquot (from 0.16 to $15 \mathrm{mg} \mathrm{mL}^{-1}$ ) or quercetin (from 0.01 to $0.16 \mathrm{mg} \mathrm{mL}^{-1}$ ) in methanol was added $3.9 \mathrm{~mL}$ of $6 \times 10^{-5} \mathrm{M}$ methanolic solution of DPPH. The mixture was shaken in a powerful way and allowed to stay in the dark at room temperature for $30 \mathrm{~min}$. The decrease in absorbance of the resulting solution was measured in spectrophotometrically at $517 \mathrm{~nm}$ against methanol. A negative control (containing all reagents except the test sample) and positive controls (using the reference antioxidants) were used as controls for this test. The ability to scavenge DPPH radical was calculated by the following equation: of control at $734 \mathrm{~nm})] \times 100$. The total antioxidant capacity value in a sample was assessed as TEAC. The TEAC value was calculated using a regression equation between the Trolox concentration and the percentage of inhibition of absorbance at $734 \mathrm{~nm}$ at 6 min of incubation and was expressed as mmol TEAC.

\section{Ferric reducing antioxidant power (FRAP) assay}

The reducing activity was determined according to the method described by Benzie and Strain [26]. The FRAP reagent included $2.5 \mathrm{~mL}$ of $10 \mathrm{mM}$ TPTZ solution in $40 \mathrm{mM} \mathrm{HCl}$ plus $2.5 \mathrm{~mL}$ of $20 \mathrm{mM} \mathrm{FeCl}_{3} \cdot 6 \mathrm{H}_{2} \mathrm{O}$ and $25 \mathrm{~mL}$ of $0.3 \mathrm{M}$ acetate buffer, $\mathrm{pH}$ 3.6. FRAP reagent $(900$ $\mu \mathrm{L})$. This reagent was prepared freshly and incubated at $37{ }^{\circ} \mathrm{C}$, then it was mixed with $90 \mu \mathrm{L}$ of distilled water and $30 \mu \mathrm{L}$ of the extracts (from 1.25 to $10 \mathrm{mg} \mathrm{mL}^{-1}$ ) or quercetin (from 0.02 to $0.31 \mathrm{mg} \mathrm{mL}^{-1}$ ) or water for the reagent blank. The increase was calculated at $4 \mathrm{~min}$ at $593 \mathrm{~nm}$ in absorbance. The FRAP values were calculated from a standard curve of $\mathrm{FeSO}_{4} \cdot 7 \mathrm{H}_{2} \mathrm{O}$ and expressed as $\mathrm{mM} \mathrm{Fe}{ }^{2+}$ equivalents.

\section{Superoxide radical scavenging activity}

Superoxide anion was formed with a PMS-NADH as non-enzymatically. Totally $3 \mathrm{ml}$ reaction mixtures were used including $2.82 \mathrm{~mL} 40 \mathrm{mM}$ sodium carbonate buffer

DPPH radical scavenging activity $(\%)=[1-($ Absorbance of sample at $517 \mathrm{~nm} /$ Absorbance of control at $517 \mathrm{~nm})] \times 100$.

\section{Total radical antioxidant potential (TRAP) assay}

The total radical antioxidant potential of the samples was measured using the Trolox equivalent antioxidant coefficient (TEAC) assay as described by Re et al. [25] with minor modifications. ABTS was dissolved in water to a $7 \mathrm{mM}$ concentration. ABTS radical cation was produced by reacting $\mathrm{ABTS}^{+}$stock solution with $2.45 \mathrm{mM}$ potassium persulfate (final concentration) and allowing the mixture to stand in the dark at room temperature for 12-16 $\mathrm{h}$ before use. At the beginning of the analysis day, $\mathrm{ABTS}^{+}$working solution was obtained by the dilution in $96 \%$ ethanol of the stock solution to an absorbance of $0.70 \pm 0.02$ at $734 \mathrm{~nm}$. After addition of $990 \mu \mathrm{L}$ of ABTS $^{+}$solution to $10 \mu \mathrm{L}$ of the extracts (from 0.625 to $15 \mathrm{mg} \mathrm{mL}^{-1}$ ) or quercetin (from 0.01 to $0.16 \mathrm{mg} \mathrm{mL}^{-1}$ ) or trolox standards (final concentration $0-20 \mu \mathrm{M} \mathrm{l}^{-1}$ ) in absolute ethanol, the decrease in absorbance at $734 \mathrm{~nm}$ was monitored exactly 6 min after the initial mixing. Appropriate methanol blanks were run in each assay. All determinations were carried out in triplicate. The ability to scavenge $\mathrm{ABTS}^{+}$radical was calculated by the following equation: $\mathrm{ABTS}^{+}$radical scavenging activity $(\%)=[1-($ Absorbance of sample at $734 \mathrm{~nm} /$ Absorbance consisting $1 \mathrm{mM}$ EDTA (pH 10.0), $0.03 \mathrm{~mL}$ of $0.5 \%$ bovine serum albumin, $0.03 \mathrm{~mL}$ of $2.5 \mathrm{mM}$ nitroblue tetrazolium, $0.06 \mathrm{~mL}$ of sample solution and $0.03 \mathrm{~mL}$ of $7.8 \mathrm{mM}$ $\mathrm{NADH}$. The mixture was kept at 25 or $37^{\circ} \mathrm{C}$ and reaction was carried out. The reaction started by the addition of $0.03 \mathrm{~mL}$ of $155 \mu \mathrm{M}$ PMS, and the absorbance at $560 \mathrm{~nm}$ was recorded for $60 \mathrm{~s}$. [27]. As the control, $0.06 \mathrm{~mL}$ of Dimethyl Sulfoxide (DMSO) was used. The reaction ratio was estimated from increased the absorbance proportional, then obtained results as sample scavenging activity were noted as the percentage of inhibition.

\section{Antimicrobial activity}

American Type Culture Collection (ATCC) from different bacterial stains was used for assessment of antibacterial activity. Staphylococcus aureus (ATCC 29213), Staphylococcus epidermidis (ATCC 12228), methicillinresistant MRSA (ATCC 43300) and Enterococcus faecalis (ATCC 29212) were used as Gram-positive species, and Escherichia coli (ATCC 25922), Klebsiella pneumoniae (ATCC 4352), Pseudomonas aeruginosa (ATCC 27853) were used as Gram-negative species, and as a yeast-shaped fungus Candida albicans (ATCC 10231) were determined by the microbroth dilutions technique 
the Clinical Laboratory Standards Institute (CLSI) recommendations [28]. Mueller-Hinton broth for bacteria, RPMI-1640 medium buffered to $\mathrm{pH} 7.0$ with MOPS for yeast strain was used as the test medium. Serial twofold dilutions ranging from $5000 \mu \mathrm{g} \mathrm{mL} \mathrm{m}^{-1}$ to $4.9 \mu \mathrm{g} \mathrm{mL}$ were prepared in medium. The inoculum was prepared using a $4-6 \mathrm{~h}$ broth culture of each bacteria and $24 \mathrm{~h}$ culture of yeast strains adjusted to a turbidity equivalent to a $0.5 \mathrm{Mc}$ Farland standard, diluted in broth media to give a final concentration of $5 \times 10^{5} \mathrm{cfu} \mathrm{mL}^{-1}$ for bacteria and $0.5 \times 10^{3}-2.5 \times 10^{3} \mathrm{cfu} \mathrm{mL}^{-1}$ for yeast in the test tray. The trays were covered and placed in plastic bags to prevent evaporation. The trays containing Mueller-Hinton broth were incubated at $35^{\circ} \mathrm{C}$ for $18-20 \mathrm{~h}$ and the trays containing RPMI- 1640 medium were incubated at $35^{\circ} \mathrm{C}$ for 46-50 h. The Minimum Inhibitory Concentration (MIC) was defined as the lowest concentration of compound giving complete inhibition of visible growth. As control, antimicrobial effects of the samples were investigated against test microorganisms. According to values of the controls, the results were evaluated.

\section{Statistical analysis}

All experiments were repeated three times and they were subjected to two-way analysis of variance (ANOVA) considering as factors the FYM and $\mathrm{AN}$, and four levels of FYM applications $\left(7.5,10,12.5\right.$ and $\left.15 \mathrm{tha}^{-1}\right)$ and AN $\left(30,60,90\right.$ and $\left.120 \mathrm{~kg} \mathrm{ha}^{-1}\right)$ with a control, while means were compared according to LSD test $(p<0.05)$. All the analyses were performed with the JMP 13 software.

\section{Results and discussion}

\section{Essential oil and components}

There were statistically significant differences between the leaves, seeds and herbs (various parts) of dill grown with FYM and AN with respect to the essential oil and components $(p<0.05)$. Essential oil yield showed differences depending on the dose of FYM and AN fertilizer applications and varied between the different parts of the dill (Table 2). The essential oil content range was found to be $0.26 \pm 0.12$ to $0.72 \pm 0.52 \%$ in dill herbs, $0.27 \pm 0.12$ to $1.70 \pm 0.08 \%$ in dill leaves, and $4.58 \pm 0.16$ to $6.18 \pm 0.55 \%$ in dill seeds. The highest leaf, seed and herb essential oil contents were obtained from the treatment of $15 \mathrm{tha}^{-1}$ FYM. In addition, the control application exhibited significantly higher essential oil content compared to all AN applications involving the use of dill leaves and herbs. Compared to the all essential oils, dill seeds had the highest essential oil yield, followed by leaves and herbs (Table 2). FYM applications of up to $15 \mathrm{t} \mathrm{ha}^{-1}$ increased the essential oil yield of dill, which may be related to the presence of more nutrients or effects of organic manure on soil structure [29].

The essential oil yield $(0.26 \pm 0.12-6.18 \pm 0.55 \%)$ obtained from the current study was comparable to that reported in a study by Krüger and Hammer [30] who found that the essential oil percentage of different dill seeds varied from 1.91 to $7.25 \%$. Similarly, Badoc and Lamarti [31] observed that the oil content of European dill seeds varied from 1.75 to $5.8 \%$. In the current study, the essential oil content of dill seeds was within the ranges reported in these previous studies. In contrast, Stanojeviš et al. [32] reported the yield of the dill essential oils from seeds and herbs to be 4 and $2.80 \%$, respectively. Furthermore, Said-Al Ahl and Omer [33] determined

Table 2 Leaf, seed and herb essential oil content and total phenolic content of the dried herbs of A. graveolens in the aqueous extract

\begin{tabular}{|c|c|c|c|c|c|}
\hline \multirow[t]{2}{*}{ Treatments } & \multicolumn{3}{|c|}{ Essential oil content (\%) } & \multicolumn{2}{|c|}{ Phenolic content $\left(\mathrm{mg} \mathrm{g}^{-1}\right)$} \\
\hline & Leaf & Seed & Herb & Infusion & Decoction \\
\hline Control & $1.47 \pm 0.52^{c}$ & $5.59 \pm 0.34^{d}$ & $0.65 \pm 0.26^{b}$ & $15.51 \pm 0.47^{c}$ & $15.71 \pm 0.45^{c}$ \\
\hline $30 \mathrm{~kg} \mathrm{ha}^{-1} \mathrm{AN}$ & $1.33 \pm 0.45^{d}$ & $5.98 \pm 0.63^{b}$ & $0.34 \pm 0.33^{d}$ & $10.19 \pm 0.37^{9}$ & $10.12 \pm 0.47^{\mathrm{e}}$ \\
\hline $60 \mathrm{~kg} \mathrm{ha}^{-1} \mathrm{AN}$ & $0.23 \pm 0.02^{h}$ & $4.63 \pm 0.47^{h}$ & $0.26 \pm 0.12^{f}$ & $18.36 \pm 0.35^{\mathrm{a}}$ & $17.85 \pm 0.24^{\mathrm{a}}$ \\
\hline $90 \mathrm{~kg} \mathrm{ha}^{-1}$ AN & $0.30 \pm 0.17^{f}$ & $5.26 \pm 0.61^{f}$ & $0.26 \pm 0.28^{f}$ & $10.06 \pm 0.34^{9}$ & $10.20 \pm 0.60^{e}$ \\
\hline $120 \mathrm{~kg} \mathrm{ha}^{-1} \mathrm{AN}$ & $0.30 \pm 0.03^{f}$ & $5.23 \pm 0.52^{9}$ & $0.35 \pm 0.45^{d}$ & $17.28 \pm 0.14^{b}$ & $16.93 \pm 0.95^{b}$ \\
\hline 7.5 tha $^{-1}$ FYM & $0.27 \pm 0.12^{9}$ & $4.58 \pm 0.16^{1}$ & $0.30 \pm 0.23^{e}$ & $12.42 \pm 0.38^{d}$ & $12.38 \pm 0.50^{d}$ \\
\hline 10 tha $^{-1}$ FYM & $0.55 \pm 0.03^{e}$ & $5.56 \pm 0.53^{e}$ & $0.64 \pm 0.15^{b}$ & $11.06 \pm 0.35^{e}$ & $11.66 \pm 0.53^{d}$ \\
\hline $12.5 \mathrm{tha}^{-1} \mathrm{FYM}$ & $1.50 \pm 0.01^{b}$ & $5.91 \pm 0.93^{c}$ & $0.55 \pm 0.07^{c}$ & $10.57 \pm 0.34^{\mathrm{ef}}$ & $10.27 \pm 0.23^{e}$ \\
\hline 15 tha $^{-1}$ FYM & $1.70 \pm 0.08^{\mathrm{a}}$ & $6.18 \pm 0.55^{\mathrm{a}}$ & $0.72 \pm 0.52^{\mathrm{a}}$ & $10.69 \pm 0.23^{e f}$ & $10.48 \pm 0.29^{e}$ \\
\hline
\end{tabular}

AN Ammonium nitrate, FYM Farmyard manure

*There was no significant difference at $p<0.05$

Average value of three replicates

Values with different letters in the same column indicate significant differences at $p<0.05$ 
that the essential oil content of Egyptian dill herbs ranged from 1.933 to $3.267 \%$. Such variations in the essential oil content of dill across countries can be attributed to the varied agroclimatic conditions of different geographical regions, as well as different fertilizer applications.

We found some differences in the quantity of the main components of essential oils extracted from different parts of dill. The total oil compositions of leaves were found to be in the range of $64.08-84.33 \%$ with dill apiole, carvotanacetone, $\alpha$-phellandrene and limonene being the most abundant compounds constituting around 22.02 to $43.55 \%$ of the investigated total concentration of essential oils (Table 3 ). In seeds, 21 constituents were identified (76.37-90.84\% of total oil samples) with limonene, dill apiole, $\alpha$-phellandrene, dihydrocarvone and carvotanacetone being the most abundant compounds that totally constituted around $48.73-67.91 \%$ of the investigated essential oils (Table 3).

Table 3 shows that 7 compounds (limonene, 4-isopropyltoluen, $\alpha$-phellandrene, dill ether, carvone, $\alpha$-pinene and myrcene) clearly dominated the dill herbs essential oil, representing $42.26-56.43 \%$ of the total concentration of essential compounds. The percentages of dill apiole and carvantonacetone varied in leaves $(2.62 \pm 0.05-11.96 \pm 0.83 \%$ and $2.98 \pm 0.22-$ $15.90 \pm 2.34 \%$, respectively), herbs $(0.87 \pm 0.03-$ $2.05 \pm 0.23 \%$ and $1.41 \pm 0.23-1.89 \pm 0.23 \%$, respectively) and seeds $(13.55 \pm 1.13-18.65 \pm 1.89 \%$ and $5.04 \pm 0.62-$ $21.76 \pm 1.62 \%$, respectively). Dill ether was present in leaves $(5.42 \pm 0.52-6.89 \pm 0.52 \%)$ and herbs $(3.79 \pm 0.78-$ $9.01 \pm 1.12 \%)$, but was found only in a small amount in seeds $(1.11 \pm 0.18-2.53 \pm 0.22 \%)$. The highest limonene content was obtained from seeds $(10.23 \pm 0.52-$ $20.05 \pm 0.45 \%)$, followed by leaves $(7.44 \pm 0.23-$ $9.38 \pm 0.56 \%)$, and herbs $(3.79 \pm 0.78-9.01 \pm 1.11 \%)$. In addition, the principal essential oil components of dill seeds and leaves were $\alpha$-phellandrene $(7.99 \pm 1.11-$ $10.79 \pm 1.26 \%$ and $5.62 \pm 0.65-10.89 \pm 1.01 \%$, respectively), dihydrocarvone $(8.08 \pm 1.02-12.11 \pm 1.32 \%$ and $1.78 \pm 0.12-8.31 \pm 1.18 \%$, respectively), and $\beta$-phellandrene $\quad(0.04 \pm 0.01-5.21 \pm 0.32 \% \quad$ and $3.61 \pm 0.26-8.12 \pm 0.22 \%$, respectively), but herb oil contained $\alpha$-phellandrene $\quad(3.72 \pm 0.23-7.21 \pm 0.86 \%)$, $\beta$-phellandrene $(5.11 \pm 0.56-7.08 \pm 0.76 \%)$, and dihydrocarvone (1.22 $\pm 0.12-1.70 \pm 0.23 \%)$. Therefore, the highest concentrations of limonene, dill apiole and carvotanacetone, which were the main components, were obtained from the essential oil extracted from seeds.

In dill leaves, the maximum concentration of carvotanacetone was obtained after applying $10 \mathrm{t} \mathrm{ha}^{-1} \mathrm{FYM}$, followed by $90 \mathrm{~kg} \mathrm{ha}^{-1} \mathrm{AN}$, whereas the maximum concentration of dill apiole was obtained after applying 10 and $7.5 \mathrm{t} \mathrm{ha}^{-1} \mathrm{FYM}$, followed by $30 \mathrm{~kg} \mathrm{ha}^{-1} \mathrm{AN}$ and $12.5 \mathrm{t}$ $\mathrm{ha}^{-1}$ FYM. The contents of carvotanacetone and dill apiole were higher in FYM applications than in AN applications. The highest concentration of dihydrocarvone was also found with the FYM application dose of $15 \mathrm{t} \mathrm{ha}^{-1}$, followed by $120 \mathrm{~kg} \mathrm{ha}^{-1} \mathrm{AN}$, whereas the lowest concentration was observed in the FYM application of $7.5 \mathrm{t}$ $\mathrm{ha}^{-1}$. Furthermore, $\alpha$-phellandrene was also prevalent in almost all treatments. The FYM dose of $15 \mathrm{t} \mathrm{ha}^{-1}$ had the highest $\alpha$-phellandrene content, followed by $12.5 \mathrm{t} \mathrm{ha}^{-1}$ FYM and $30 \mathrm{~kg} \mathrm{ha}^{-1}$ AN (Table 3).

In dill herbs, all treatments resulted in similar percentages $\beta$-phellandrene $(5.11 \pm 0.56-7.08 \pm 0.76 \%)$, whereas the $10 \mathrm{t} \mathrm{ha}^{-1} \mathrm{FYM}$ application provided the highest $\alpha$-phellandrene content at $7.08 \%$ (Table 3). The highest rates of limonene and myrcene were obtained from the FYM doses of $15 \mathrm{tha}^{-1}$ and $90 \mathrm{~kg} \mathrm{ha}^{-1} \mathrm{AN}$, respectively, which significantly differed compared to the remaining doses and the control treatment. Therefore, dill herb and leave oil were found suitable for the production of $\alpha$-phellandrene, limonene as a fragrance component in food, detergents, cosmetics, perfumes, and especially soaps, and they would also have economical value for the grower [34].

Dill ether was identified at the highest level after applying $60 \mathrm{~kg} \mathrm{ha}^{-1} \mathrm{AN}$ and the control application, followed by $12.5 \mathrm{t} \mathrm{ha}^{-1}$ and $15 \mathrm{t} \mathrm{ha}^{-1}$ FYM. Also, 4-isopropyltoluen and $\alpha$-phellandrene had higher concentrations in the treatment with $90 \mathrm{~kg} \mathrm{ha}^{-1} \mathrm{AN}$, followed by $120 \mathrm{~kg} \mathrm{ha}^{-1}$ $\mathrm{AN}$ and $12.5 \mathrm{t} \mathrm{ha}^{-1}$ FYM. In dill seeds, the highest concentrations $(5.04 \pm 0.62-21.76 \pm 1.62 \%)$ for carvantonacetone was obtained from the FYM application at a dose of $15 \mathrm{t} \mathrm{ha}^{-1}$, whereas the lowest concentration was obtained from $120 \mathrm{~kg} \mathrm{ha}^{-1} \mathrm{AN}$. The highest concentration of limonene was also found after the FYM treatment at a dose of $12.5 \mathrm{t} \mathrm{ha}^{-1}$, whereas the lowest concentration was observed after the application of $10 \mathrm{tha}^{-1} \mathrm{FYM}$. Similarly, apiole was present in almost all treatments. The FYM dose of $7.5 \mathrm{t} \mathrm{ha}^{-1}$ resulted in the highest apiol content, followed by $90 \mathrm{~kg} \mathrm{ha}^{-1} \mathrm{AN}, 12.5 \mathrm{t} \mathrm{ha}^{-1}$ FYM and the control application. Apiole and dillapiole are effective, naturally occurring insecticides or insecticide synergists. Based on the results obtained, it is considered that dill seeds would be suitable for the production of apiole to be used in insecticides to act in synergy with pyrethrin and inhibit aflatoxin [35].

Dihydrocarvone was found in the application of FYM at a dose of $12.5 \mathrm{tha}^{-1}$, followed by $30 \mathrm{~kg} \mathrm{ha}^{-1} \mathrm{AN}$ and $90 \mathrm{~kg} \mathrm{ha}^{-1} \mathrm{AN}$. The highest $\alpha$-phellandrene was obtained from $120 \mathrm{~kg} \mathrm{ha}^{-1} \mathrm{AN}$, followed by $90 \mathrm{~kg} \mathrm{ha}^{-1} \mathrm{AN}$ and 15 $\mathrm{t} \mathrm{ha}^{-1}$ FYM. Today, dihydrocarvone or carvone have both pharmaceutical and cosmetic uses, and some important applications in agriculture both for crop protection and as an antisprouting agent during tuber storage. Dill seed 


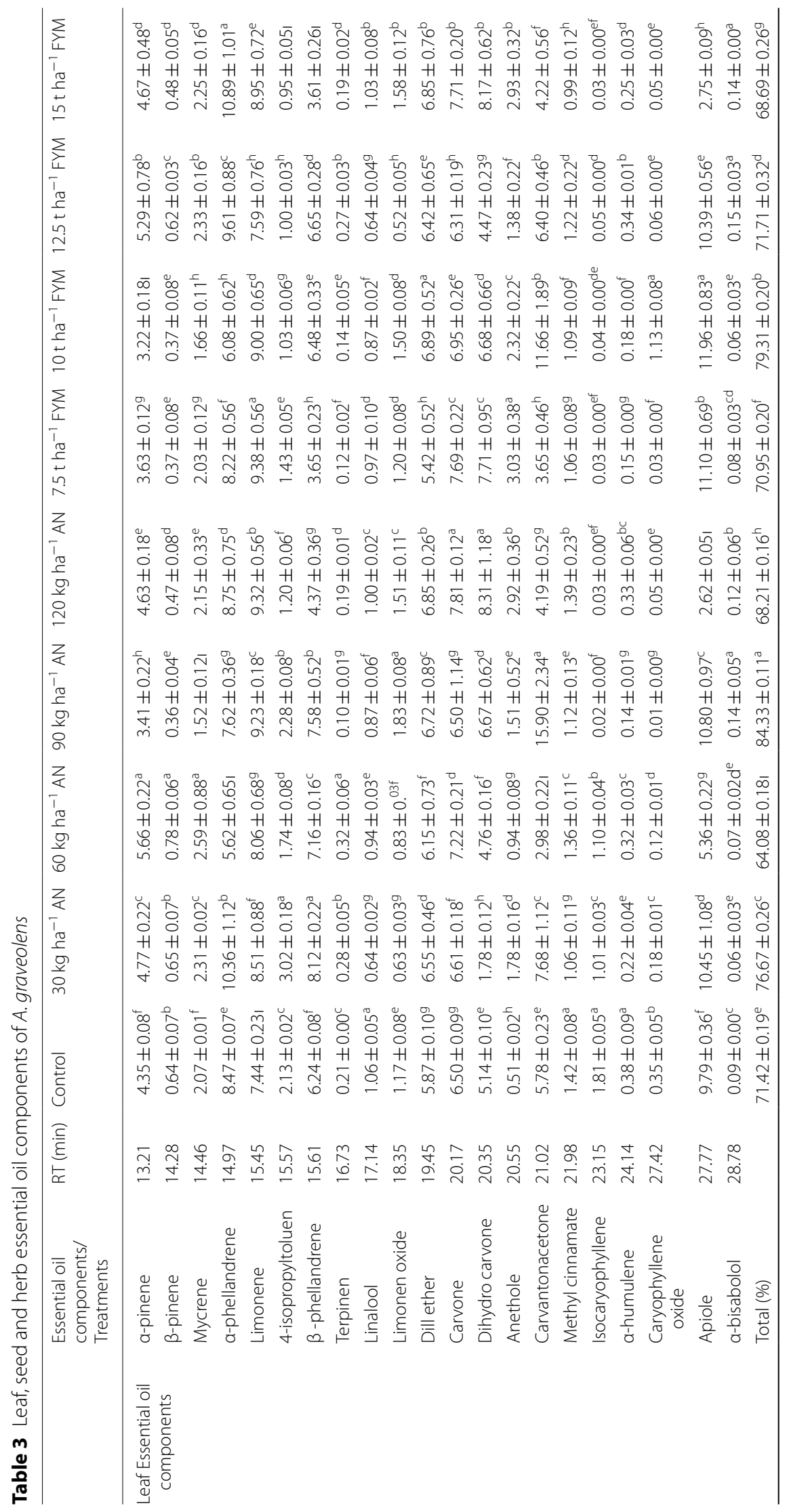




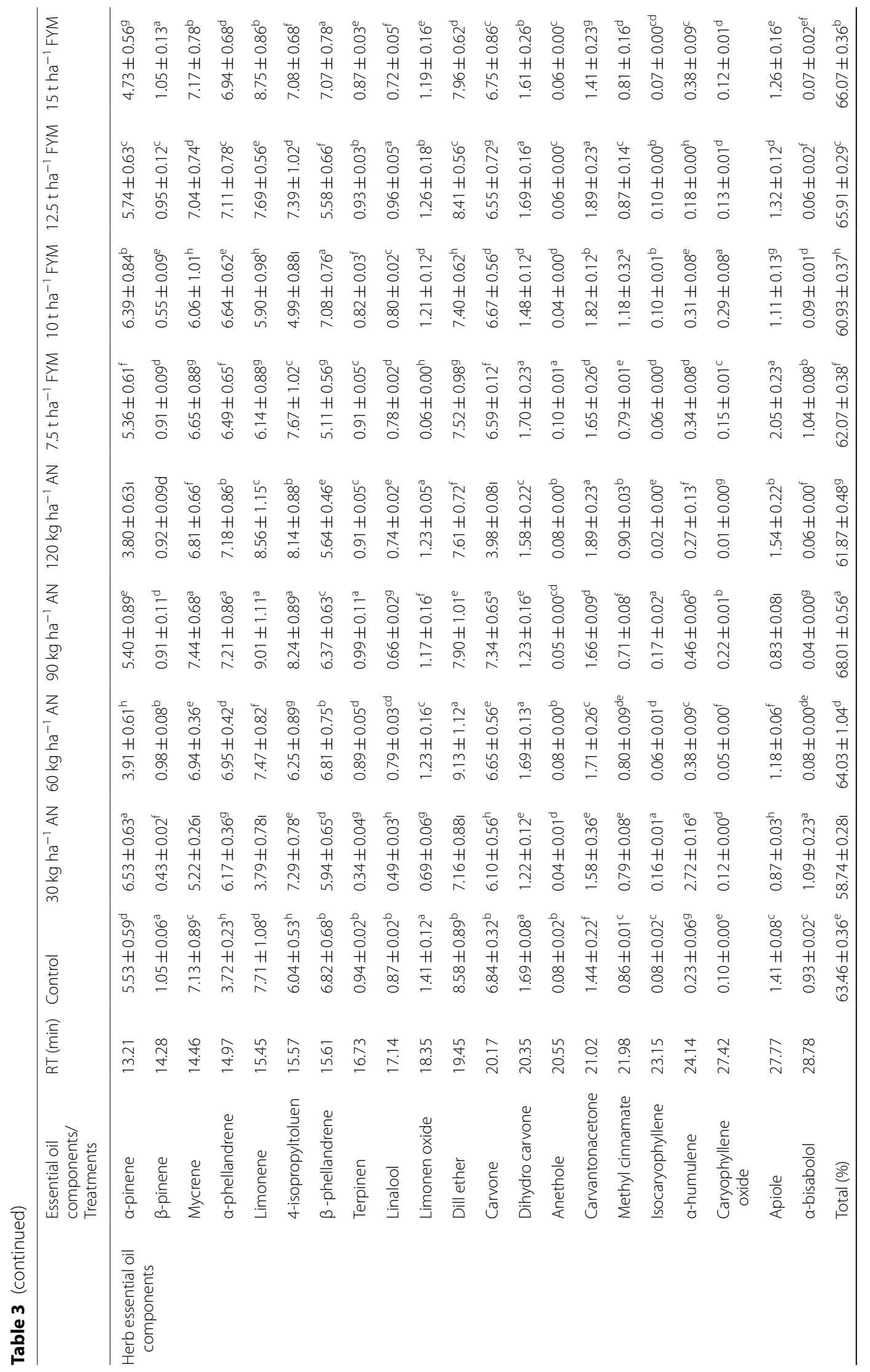




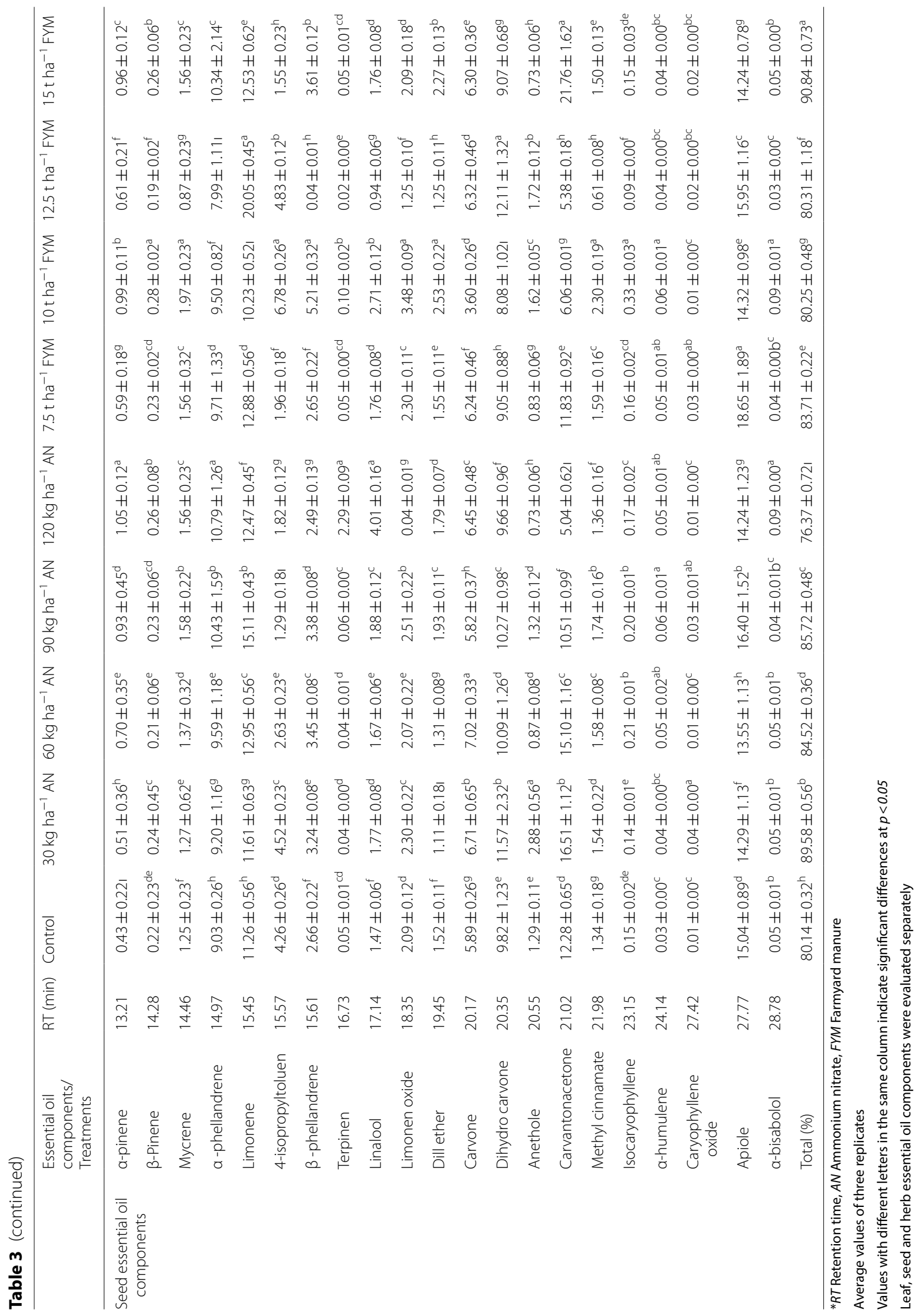


oil is also suitable for the production of dihydrocarvone or carvone used in traditional and new food products, including chewing gum, as well as in cosmetics and perfumes [36].

According to our result, FYM application contributed not only to an increase in essential oil content, but also increased the concentration of carvantonacetone, $\alpha$-phellandrene, limonene and myrcene in the oil. Furthermore, we also noted that FYM application of up to 15 $\mathrm{t} \mathrm{ha}^{-1}$ of increased the EO component yield effectively, which could be caused by the overall promotion effect of organic manure on the secondary metabolic pathways of the plants $[37,38]$.

The results of the current study were closely related to those reported by Hussein et al. [39], who determined the major components of dill vegetative herb essential oils as $\alpha$-phellandrene $(46.33 \%)$, limonene (13.72\%), $\beta$-phellandrene (11.01\%), p-cymene (17.88\%), and carvone (13.10\%), whereas carvone $(62.48 \%)$, dillapiole (19.51\%) and limonene (14.61\%) were identified as the major compounds in seed essential oil. Furthermore, Ruangamnart et al. [40] indicated the major components of dill seeds oils in Thailand were dillapiole (19.98-48.9\%), carvone (18.05-28.02\%), and limonene (26.96-44.61\%). Similarly, Kazemi [41] reported the major components of dill herb oils as $\alpha$-phellandrene (19.12\%), limonene (26.34\%), dill ether (15.23\%), sabinene (11.34\%).

In another study, Madandoust and Fooladchang [42] determined the effect of different nitrogen doses (50, 100 and $150 \mathrm{~kg} \mathrm{ha}^{-1}$ ) on dill essential oil to be within the ranges of $2.00-2.25 \%\left(\mathrm{v} \mathrm{w}^{-1}\right)$. The authors also indicated that the highest essential oil was obtained from $100 \mathrm{~kg} \mathrm{ha}^{-1} \mathrm{~N}$ and identified 17 compounds. Among the major components, the highest concentrations of $\alpha$-phellandrene $(49.54 \%)$ and limonene $(13.79 \%)$ were obtained from the $150 \mathrm{~kg} \mathrm{ha}^{-1}$ application, while the highest p-cymene concentration (18.19\%) was seen in the $50 \mathrm{~kg} \mathrm{ha}^{-1}$ application, and $\beta$-phellandrene $(9.0 \%)$ in the control group. This is in agreement with our results, revealing that the essential oil and major components of dill were increased at a nitrogen dose of up to $120 \mathrm{~kg} \mathrm{ha}^{-1}$.

Moreover, Darzi et al. [43] emphasized the importance of bioorganic manure with respect to enhancement of the essential oils and components of dill seed. The highest values of essential oil content and components were obtained in dill plants grown in 4 and $8 \mathrm{tha}^{-1}$ vermicompost treatments. This result is partly in agreement with our finding indicating that the FYM application of up to $15 \mathrm{t} \mathrm{ha}^{-1}$ effectively increased the essential oil and component yield.
In contrast, Jianu et al. [44] identified the major components of dill mature seeds oils as carvone $(52.37 \%)$ and limonene $39.20 \%$. They also reported that the carvone concentration $(34.62 \%)$ was lower than that of limonene $(40.69 \%)$ in immature seeds. Singh et al. [45] noted that the major components of dill mature seed oils were carvone (55.2\%), limonene (16.6\%), dill apiole (43.2\%) and linoleic acid (23.1\%). In addition, Sharopov et al. [46] reported that the major components of dill aerial oils were carvone (51.7\%), trans- dihydrocarvone (14.7\%), dill ether (13.2\%), $\alpha$-phellandrene (8.1\%), and limonene (6.9\%).

The chemical profile of our dill essential oil sample contradicts the data reported by Singh et al. [44] and Sharopov et al. [46]. These differences in the chemical composition of oils may arise from several environmental and genetic differences and the nutritional status of the plants.

\section{Phenolic contents}

The results given in Table 2 showed that the mean of the total phenolic content per gram crude extract of both the $60 \mathrm{~kg} \mathrm{ha}^{-1}$ AN infusion and decoction preparations $\left(18.36 \pm 0.35\right.$ and $17.85 \pm 0.24 \mathrm{mg}$ GAE $\mathrm{g}^{-1}$, respectively) as well as $120 \mathrm{~kg} \mathrm{da}^{-1} \mathrm{AN}$ infusion and decoction $\left(17.28 \pm 0.14\right.$ and $16.93 \pm 0.95 \mathrm{mg} \mathrm{GAE} \mathrm{g}^{-1}$, respectively) are significantly higher $(p<0.05)$ than that of infusion control $\left(15.51 \pm 0.47 \mathrm{mg} \mathrm{GAE} \mathrm{g}^{-1}\right)$ and decoction control $\left(15.71 \pm 0.45 \mathrm{mg} \mathrm{GAE} \mathrm{g}^{-1}\right)$.

So they can be considered as the good source of antioxidants due to their high level of phenolic compounds. $60 \mathrm{~kg} \mathrm{da}^{-1}$ AN infusion and $120 \mathrm{~kg} \mathrm{da}^{-1}$ AN decoction showed the similar antioxidant profile and content of phenols, indicating that the type of phenolic compounds in infusion and decoction did not varied markedly.

Infusion extracts were the most effective amongst all the tested extracts having a high content of total phenols. However, the essential oil extracts of dill herb were found to have no phenolic content all FYM and AN applications. A comparison of FYM and AN applications indicated that AN fertilizer extracts exhibited the highest phenolic content. Among the FYM extracts, the highest phenolic contents were found in treatments with decoction and infusion extract of 750 and $10 \mathrm{t} \mathrm{ha}^{-1} \mathrm{FYM}$, which were slightly different compared to the other treatments and the control treatment (Table 2).

Our results were comparable with the results described by Albayrak et al. [47] who found that the total phenolic content of dill infusion and decoction extracts were equivalent to 12.13 and $15.45 \mathrm{mg} \mathrm{GAE} \mathrm{g}^{-1}$, respectively. However, our values were greater than that reported by Zheng and Wang [48] report which determined that total phenolic contents of dill were $3.12 \mathrm{mg}$ of $\mathrm{GAE} \mathrm{g}^{-1}$ 
of fresh weight. This discrepancy may be due to the additional contribution of FYM to the total phenolic amount. Our results were consistent with the previous observation on the total phenolic content of dill extracts using bio-fertilizer compared to chemical fertilizer $[49,50]$.

\section{Antioxidant activity}

The use of infusion and decoction of dill as a complement to daily food intake can provide considerable benefits for health, not only in the treatment of diseases related to reactive species production and oxidative stress but also against bacterial infections. These benefits of dill can be achieved through both internal and external use, and at recommended doses, it is safe with no adverse reactions having been described to date.

In the present study, the water extracts prepared as infusion and decoction and essential oils were screened for their antioxidant activities using 2,2,-diphenyl-1-picrylhydrazyl free radical and superoxide anion scavenging, trolox equivalent antioxidant capacity (TEAC) assay with ABTS $^{*+}$ radical cation and ferric reducing antioxidant power (FRAP) assays. For comparison, Table 4 presents the results of the antioxidant activities, expressed as $\mathrm{EC}_{50}$ values.

From the $\mathrm{EC}_{50}$ values estimated from the doseresponse curves, it was seen that infusions, decoctions and essential oils showed similar degrees of efficacy in scavenging DPPH, $\mathrm{ABTS}^{\circ+}$ and superoxide anion radicals as shown by the small differences of the $\mathrm{EC}_{50}$ values.

Both the infusions and decoctions as well as essential oils showed the DPPH, ABTS and superoxide radical scavenging activities in a dose-dependent manner. From the $\mathrm{EC}_{50}$ values (the effective concentration at which the DPPH, ABTS and superoxide anion radicals were scavenged by $50 \%$ ), it was seen that among the infusions $60 \mathrm{~kg} \mathrm{ha}^{-1} \mathrm{AN}$ showed the highest DPPH, ABTS and superoxide radical scavenging activity as shown by the lowest value of $2.27 \pm 0.10,2.63 \pm 0.11$ and $2.42 \pm 0.11 \mathrm{mg} \mathrm{mL}^{-1}$, respectively.

Among the decoctions $120 \mathrm{~kg} \mathrm{ha}^{-1}$, AN showed the highest DPPH, ABTS and superoxide radical scavenging activities as shown by the lowest values of $2.39 \pm 0.12$, $2.72 \pm 0.11$ and $2.49 \pm 0.10 \mathrm{mg} \mathrm{mL}^{-1}$, respectively. These findings are in agreement with our observation on phenolic contents of the $60 \mathrm{~kg} \mathrm{ha}^{-1} \mathrm{AN}$ infusion and $12 \mathrm{~kg} \mathrm{ha}^{-1}$ AN decoction and seem to suggest phenolics to be important contributors to their antioxidant activity.

Among the essential oils the best DPPH, ABTS and superoxide anion radical scavenging activity were shown by $7.5 \mathrm{tha}^{-1} \mathrm{FYM}$, and $10 \mathrm{tha}^{-1} \mathrm{FYM}$. The $\mathrm{EC}_{50}$ values of $60 \mathrm{~kg} \mathrm{ha}^{-1}$ AN infusion, $120 \mathrm{~kg} \mathrm{ha}^{-1}$ AN decoction as well as $7.5 \mathrm{tha}^{-1}$ FYM and $10 \mathrm{tha}^{-1}$ FYM essential oils were significantly lower compared to that of control $(p<0.05)$.
These results suggested that the above-mentioned samples possess the strongest free radical scavenging activity. However, when compared to reference antioxidant, gallic acid, all the tested samples showed significantly $(p<0.05)$ lower radical scavenging activities.

The ABTS radical scavenging activity, measured at 6 min of incubation with ABTS radical cation was also expressed as the TEAC value. The TEAC reflects the ability of electron-donating antioxidants to scavenge the ABTS $^{*+}$ radical cation compared to that of Trolox. The TEAC value is a quantification of the effective antioxidant activity of the extracts. Table 3 presents the results of antioxidant activities of the samples, expressed as TEAC and FRAP values. At $10 \mathrm{mg} \mathrm{mL}^{-1}, 60 \mathrm{~kg} \mathrm{ha}^{-1} \mathrm{AN}$ and 7.5 $\mathrm{t}$ ha ${ }^{-1}$ FYM infusions, and $120 \mathrm{~kg} \mathrm{ha}^{-1} \mathrm{AN}$ decoction as well as at $10 \mathrm{mg} \mathrm{mL}^{-1} 7.5 \mathrm{t} \mathrm{ha}^{-1} \mathrm{FYM}$ and $10 \mathrm{t} \mathrm{ha}^{-1} \mathrm{FYM}$ essential oils showed high antioxidant potential with high TEAC value of $2.0 \mathrm{mM}$ Trolox, which corresponded to a high phenolic content of these samples. The TEAC value of the mentioned samples at $10 \mathrm{mg} \mathrm{mL}^{-1}$ was comparable to that of gallic acid $(2.051 \pm 0.004)$ at $0.8 \mathrm{mg} \mathrm{mL}^{-1}$ (Table 3).

In addition to their scavenging properties, infusion and decoction samples also showed high ferric reducing ability. In this assay, the antioxidant activity was determined on the basis of the ability of the samples to reduce ferric (III) iron to ferrous (II) iron. The results were expressed as $\mathrm{mM}$ ferrous ion equivalents. The higher FRAP value would imply greater antioxidant activity of the sample. At a concentration of $10 \mathrm{mg} \mathrm{mL} \mathrm{m}^{-1}, 60 \mathrm{~kg} \mathrm{ha}^{-1} \mathrm{AN}$ infusion, $7.5 \mathrm{t} \mathrm{ha}^{-1} \mathrm{FYM}$ infusion, $60 \mathrm{~kg} \mathrm{ha}^{-1} \mathrm{AN}$ decoction and $120 \mathrm{~kg} \mathrm{ha}^{-1} \mathrm{AN}$ decoction had the reducing powers similar to that of gallic acid at $0.8 \mathrm{mg} \mathrm{mL}^{-1}$ (Table 5). This data re-inforced the greater antioxidant activity of the $60 \mathrm{~kg} \mathrm{ha}^{-1} \mathrm{AN}$ infusion and $120 \mathrm{~kg} \mathrm{ha}^{-1}$ AN decoction in the DPPH, ABTS and superoxide anion radical scavenging assays compared to other samples. With regard to the FRAP values, the essential oils were considerably less effective $(p<0.05)$ reductions compared to the infusions and decoctions. At a concentration of $\mathrm{mg} 10 \mu \mathrm{l}^{-1}$, the most effective reductions were $7.5 \mathrm{tha}^{-1}$ FYM and 10 $\mathrm{t} \mathrm{ha}^{-1}$ FYM essential oils. This indicated that the highest antioxidant activity might be attributed to the combined effects of reducing power, scavenging of radicals and donation of electrons. These results were in very good agreement with that of different extracts of dill, indicating comparable or higher antioxidant activity $[41,47,48$, $51-54]$.

On the other hand, Albayrak et al. [47] evaluated the antioxidant activities of 19 dill extracts and reported the highest antioxidant potential for methanol extract, followed by infusion, while decoction was found to be the least effective antioxidant. Similarly, Shyu et al. 


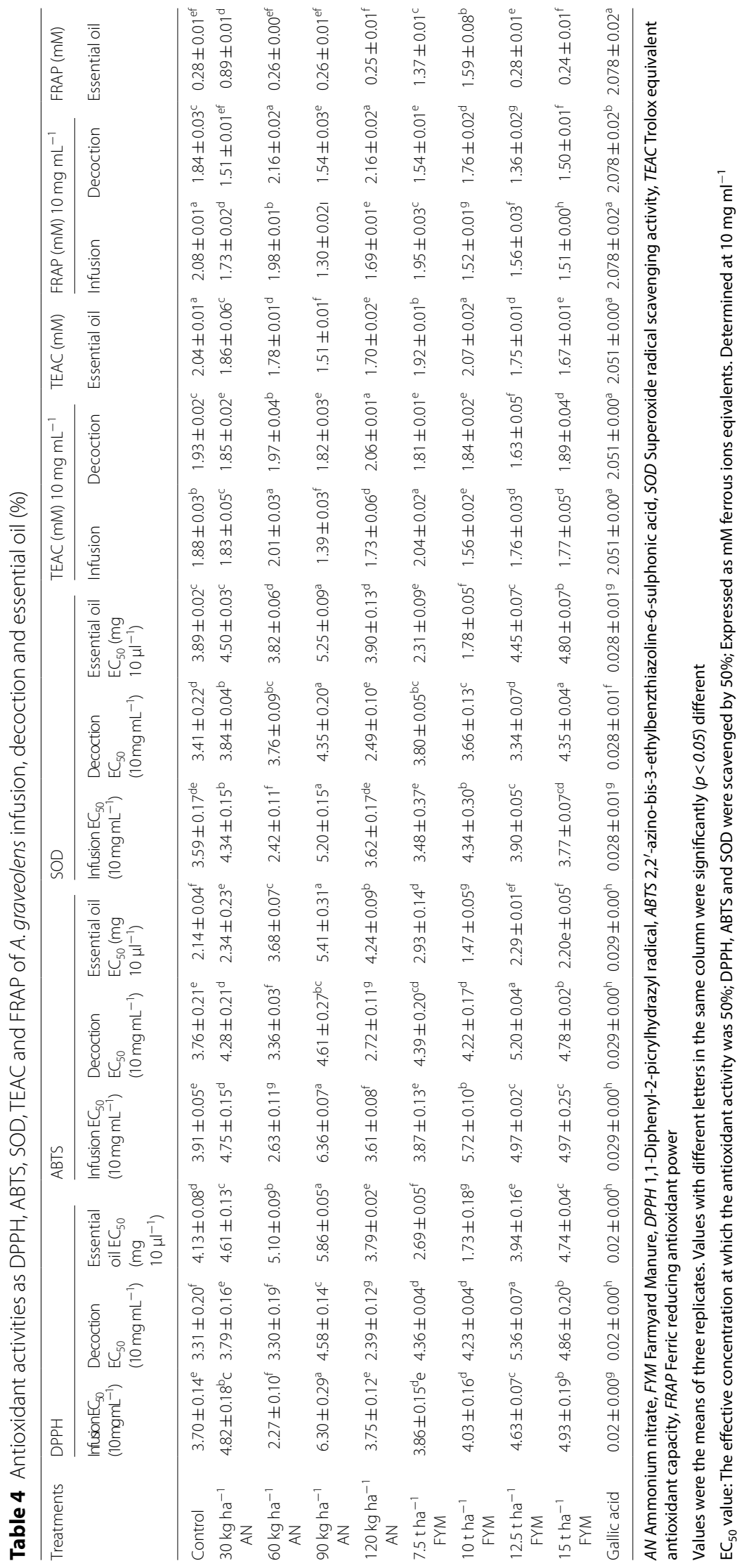


Table 5 DPPH; ABTS ${ }^{+}$and SOD percentages, TEAC and FRAP values depending on the gallic acid concentrations

\begin{tabular}{|c|c|c|c|c|c|}
\hline Gallic acid $\left(\mathrm{mg} \mathrm{mL}^{-1}\right)$ & DPPH. (\%) & $\mathrm{ABTS}^{+}(\%)$ & SOD (\%) & TEAC $\left(\mathrm{mM} \mathrm{I}^{-1}\right)$ & $\operatorname{FRAP}\left(\mathrm{mM} \mathrm{I}^{-1}\right)$ \\
\hline 0.16 & $98.90 \pm 0.74^{a}$ & $97.50 \pm 0.95^{\mathrm{a}}$ & $94.19 \pm 0.69^{a}$ & $2.05 \pm 0.00^{\mathrm{a}}$ & $3.48 \pm 0.02^{\mathrm{a}}$ \\
\hline 0.08 & $98.90 \pm 0.074^{a}$ & $97.50 \pm 0.95^{\mathrm{a}}$ & $61.50 \pm 0.60^{b}$ & $2.05 \pm 0.00^{\mathrm{a}}$ & $2.20 \pm 0.02^{b}$ \\
\hline 0.04 & $90.44 \pm 0.88^{b}$ & $71.82 \pm 4.12^{\mathrm{b}}$ & $43.38 \pm 0.76^{c}$ & $1.50 \pm 0.05^{b}$ & $1.18 \pm 0.01^{c}$ \\
\hline 0.02 & $51.96 \pm 0.99^{c}$ & $47.69 \pm 3.08^{c}$ & $34.87 \pm 1.74^{d}$ & $1.02 \pm 0.06^{c}$ & $0.78 \pm 0.02^{d}$ \\
\hline 0.01 & $22.41 \pm 0.36^{d}$ & $28.72 \pm 3.39^{d}$ & $27.30 \pm 0.60^{\mathrm{e}}$ & $0.61 \pm 0.07^{d}$ & $0.51 \pm 0.01^{\mathrm{e}}$ \\
\hline
\end{tabular}

Values were the means of three replicates

Values with different letters in the same column were significantly $(p<0.05)$ different

[53] prepared $n$-hexane, ethyl acetate and ethanol soluble fractions from ethanolic extract of dill flower, and determined that the highest antioxidant activity was found in ethyl acetate fraction, and followed by ethanol fraction, original flower extract and n-hexane fraction, respectively. Variability of antioxidant activity between these finding and previous studies can be explained by extraction conditions and methods, different genotypes, soil ecology and secondary metabolite pathways of the plants, organic and chemical fertilizer [37, 38, 55].

\section{Antimicrobial activity}

Table 6 presents the results obtained from the evaluation of the antimicrobial activity of herb and seed essential oils in the infusion and decoction extracts prepared from dill. The results showed that all herb and seed essential oils were active against all the tested microbial species, including Staphylococcus aureus ATCC 29213; Staphylococcus epidermidis ATCC 12228, Enterococcus faecalis ATCC 29212, methicillin-resistant MRSA ATCC 43300, Escherichia coli ATCC 25922, Klebsiella pneumoniae ATCC 4352, Pseudomonas aeruginosa ATCC 27853,

Table 6 Antimicrobial activities of A. graveolens herb and seed essential oils (\%)

\begin{tabular}{|c|c|c|c|c|c|c|c|c|c|}
\hline & \multirow[t]{2}{*}{ Treatments } & \multicolumn{4}{|c|}{ Gram-negative } & \multicolumn{3}{|l|}{ Gram-positive } & \multirow{2}{*}{$\begin{array}{l}\text { Fungi } \\
\text { C.a }\end{array}$} \\
\hline & & S.a & S.e & MRSA & E.f & E.C & K.p & P. $a^{*}$ & \\
\hline \multirow[t]{9}{*}{ Herb of dill } & Control & $12.50 \pm 0.20^{\mathrm{a}}$ & $12.50 \pm 0.20^{b}$ & $6.25 \pm 0.30^{b}$ & $12.50 \pm 0.36^{c}$ & $6.25 \pm 0.12^{c}$ & $6.25 \pm 0.33^{b}$ & $12.50 \pm 0.36$ & $0.80 \pm 0.03^{c}$ \\
\hline & $30 \mathrm{~kg} \mathrm{ha}^{-1} \mathrm{AN}$ & $6.25 \pm 0.20^{b}$ & $25.00 \pm 0.16^{\mathrm{a}}$ & $6.25 \pm 0.26^{b}$ & $50.00 \pm 0.42^{\mathrm{a}}$ & $12.50 \pm 0.23^{b}$ & $12.50 \pm 0.26^{a}$ & $12.50 \pm 0.22$ & $0.40 \pm 0.01^{d}$ \\
\hline & $60 \mathrm{~kg} \mathrm{ha}^{-1} \mathrm{AN}$ & $6.25 \pm 0.20^{b}$ & $3.13 \pm 0.09^{d}$ & $6.25 \pm 0.22^{b}$ & $12.50 \pm 0.36^{c}$ & $3.13 \pm 0.08^{d}$ & $3.13 \pm 0.23^{c}$ & $12.50 \pm 0.45$ & $0.80 \pm 0.03^{c}$ \\
\hline & $90 \mathrm{~kg} \mathrm{ha}^{-1} \mathrm{AN}$ & $6.25 \pm 0.30^{b}$ & $25.00 \pm 0.23^{\mathrm{a}}$ & $6.25 \pm 0.22^{b}$ & $50.00 \pm 0.50^{\mathrm{a}}$ & $12.50 \pm 0.23^{b}$ & $12.50 \pm 0.26^{\mathrm{a}}$ & $12.50 \pm 0.36$ & $0.80 \pm 0.05^{c}$ \\
\hline & $120 \mathrm{~kg} \mathrm{ha}^{-1} \mathrm{AN}$ & $6.25 \pm 0.30^{b}$ & $6.25 \pm 0.21^{c}$ & $1.60 \pm 0.08^{c}$ & $12.50 \pm 0.22^{c}$ & $6.25 \pm 0.26^{c}$ & $3.13 \pm 0.23^{c}$ & $12.50 \pm 0.36$ & $0.80 \pm 0.05^{c}$ \\
\hline & 7.5 t ha $^{-1}$ FYM & $3.13 \pm 0.18^{c}$ & $6.25 \pm 0.24^{c}$ & $1.60 \pm 0.08^{c}$ & $6.25 \pm 0.16^{d}$ & $6.25 \pm 0.26^{c}$ & $6.25 \pm 0.26^{b}$ & $12.50 \pm 0.48$ & $1.60 \pm 0.02^{b}$ \\
\hline & 10 tha $^{-1}$ FYM & $12.50 \pm 0.20^{\mathrm{a}}$ & $25.00 \pm 0.26^{\mathrm{a}}$ & $25.00 \pm 0.13^{\mathrm{a}}$ & $25.00 \pm 0.32^{b}$ & $25.00 \pm 0.63^{\mathrm{a}}$ & $12.50 \pm 0.23^{a}$ & $25.00 \pm 0.50$ & $6.25 \pm 0.10^{\mathrm{a}}$ \\
\hline & $12.5 \mathrm{tha}^{-1} \mathrm{FYM}$ & $1.60 \pm 0.16^{d}$ & $6.25 \pm 0.22^{c}$ & $6.25 \pm 0.11^{b}$ & $12.50 \pm 0.23^{c}$ & $12.50 \pm 0.22^{b}$ & $6.25 \pm 0.33^{b}$ & $6.25 \pm 0.26$ & $0.80 \pm 0.02^{c}$ \\
\hline & 15 tha $^{-1}$ FYM & $3.13 \pm 0.18^{c}$ & $3.13 \pm 0.22^{d}$ & $6.25 \pm 0.15^{b}$ & $12.50 \pm 0.25^{c}$ & $6.25 \pm 120^{c}$ & $6.25 \pm 0.32^{b}$ & $6.25 \pm 0.26$ & $0.80 \pm 0.02^{c}$ \\
\hline \multirow[t]{9}{*}{ Seed of dill } & Control & $25.00 \pm 0.50^{\mathrm{a}}$ & $25.00 \pm 0.12^{*}$ & $3.13 \pm 0.08^{d}$ & $25.00 \pm 0.12^{*}$ & $12.50 \pm 0.52^{b}$ & $0.80 \pm 0.08^{b}$ & $25.00 \pm 0.22^{a}$ & $0.10 \pm 0.01^{b}$ \\
\hline & $30 \mathrm{~kg} \mathrm{ha}^{-1} \mathrm{AN}$ & $12.50 \pm 0.23^{b}$ & $25.00 \pm 0.13$ & $6.25 \pm 0.12^{c}$ & $25.00 \pm 0.11$ & $25.00 \pm 0.86^{\mathrm{a}}$ & $0.80 \pm 0.02^{b}$ & $25.00 \pm 0.33^{a}$ & $0.10 \pm 0.01^{b}$ \\
\hline & $60 \mathrm{~kg} \mathrm{ha}^{-1} \mathrm{AN}$ & $25.00 \pm 0.42^{\mathrm{a}}$ & $25.00 \pm 0.13$ & $12.5 \pm 0.22^{b}$ & $25.00 \pm 0.12$ & $12.50 \pm 0.23^{b}$ & $0.80 \pm 0.01^{b}$ & $25.00 \pm 0.24^{a}$ & $0.10 \pm 0.01^{b}$ \\
\hline & $90 \mathrm{~kg} \mathrm{ha}^{-1} \mathrm{AN}$ & $12.50 \pm 0.46^{b}$ & $25.00 \pm 0.15$ & $0.80 \pm 0.00^{e}$ & $25.00 \pm 0.06$ & $25.00 \pm 0.62^{\mathrm{a}}$ & $0.80 \pm 0.01^{b}$ & $25.00 \pm 0.24^{a}$ & $0.10 \pm 0.01^{b}$ \\
\hline & $120 \mathrm{~kg} \mathrm{ha}^{-1} \mathrm{AN}$ & $12.50 \pm 0.12^{b}$ & $25.00 \pm 0.16$ & $6.25 \pm 0.18^{c}$ & $25.00 \pm 0.06$ & $25.00 \pm 0.32^{\mathrm{a}}$ & $0.40 \pm 0.01^{c}$ & $12.50 \pm 0.08^{b}$ & $0.05 \pm 0.00^{c}$ \\
\hline & 7.5 t ha $^{-1}$ FYM & $12.50 \pm 0.22^{b}$ & $25.00 \pm 0.18$ & $25.00 \pm 0.36^{\mathrm{a}}$ & $25.00 \pm 0.06$ & $6.25 \pm 0.08^{c}$ & $0.80 \pm 0.02^{b}$ & $25.00 \pm 0.12^{a}$ & $0.10 \pm 0.01^{b}$ \\
\hline & 10 tha $^{-1}$ FYM & $25.00 \pm 0.48^{\mathrm{a}}$ & $25.00 \pm 0.14$ & $3.13 \pm 0.12^{d}$ & $25.00 \pm 0.12$ & $25.00 \pm 0.23^{\mathrm{a}}$ & $12.50 \pm 0.13^{\mathrm{a}}$ & $25.00 \pm 0.18^{a}$ & $0.20 \pm 0.02^{\mathrm{a}}$ \\
\hline & $12.5 \mathrm{tha}^{-1} \mathrm{FYM}$ & $25.00 \pm 0.52^{\mathrm{a}}$ & $25.00 \pm 0.16$ & $3.13 \pm 0.08^{d}$ & $25.00 \pm 0.16$ & $12.50 \pm 0.08^{b}$ & $0.80 \pm 0.03^{b}$ & $25.00 \pm 0.22^{\mathrm{a}}$ & $0.10 \pm 0.01^{b}$ \\
\hline & 15 tha $^{-1}$ FYM & $12.50 \pm 0.50^{b}$ & $25.00 \pm 0.16$ & $3.13 \pm 0.16^{d}$ & $25.00 \pm 0.15$ & $12.50 \pm 0.11^{b}$ & $0.80 \pm 0.03^{b}$ & $25.00 \pm 0.31^{a}$ & $0.05 \pm 0.00^{c}$ \\
\hline
\end{tabular}

S.a: S. aureus ATCC 29213; S.e: S. epidermidis ATCC 12228; MRSA Methicillin-Resistant Staphylococcus aureus ATCC 43300; E.f: E. faecalis 29212; E.c: E. coli ATCC 25922; K.p: K. pneumoniae ATCC 4352; P.a: P. aeruginosa ATCC 27853; C.a: C. albicans ATCC 10231

*There was not any statistical differences at $p<0.05$ level

Values were the means of three replicates

Values with different letters in the same column were significantly $(p<0.05)$ different

Antimicrobial activities of dill herb and seed essential oils were evaluated separately 
Candida albicans ATCC 10231. Moreover, the FYM application at different doses increased the antimicrobial activity compared to the control treatment.

The highest antibacterial activity against all tested microbial species was observed with the $10 \mathrm{t} \mathrm{ha}^{-1} \mathrm{FYM}$ application (Table 6). The antimicrobial activity of dill grown with FYM was higher compared to the use of AN fertilizer. This high antimicrobial activity of FYM in our study can be attributed to soils fertilized with animal manure containing more potassium and other macro and trace elements [56]. When all the infusion and decoction extracts were evaluated together, the dill decoction extracts showed no activity against any of the tested microbial species, and the dill infusion extracts exhibited activity only against $E$. coli $\left(625 \mu \mathrm{g} \mathrm{ml} \mathrm{m}^{-1} \mathrm{mic}\right)$ with the $12.5 \mathrm{t} \mathrm{ha}^{-1}$ FYM application.

When all the herb essential oil extracts were evaluated together, they showed varying levels of antimicrobial activity against the tested microbial species, but the highest antimicrobial activity was observed against $E$. faecalis (50\%) in the applications of 30 and $60 \mathrm{~kg} \mathrm{ha}^{-1} \mathrm{AN}$ (Table 6). The herb essential oils also exhibited stronger antifungal activity against $P$. aeruginosa when compared with the other microbial species tested. According to the results of the herb essential oils, among all the doses of FYM, the highest antibacterial activity against almost all the tested microbial species was observed with $10 \mathrm{t} \mathrm{ha}^{-1}$ (Table 6).

According to the results of the herb and seed essential oils, the latter showed higher antibacterial activity against all the tested microbial species than the former. Furthermore, the seed essential oils exhibited strong antifungal activity against $S$. epidermidis, E. faecalis, and P. aeruginosa. The rate of inhibition was greater on gram-negative bacteria (P. aeruginosa) than that observed on gram-positive bacterium (S. epidermidis, E. faecalis). The variation between the antibacterial activity of essential oils against Gram-negative and Gram-positive bacteria depends on several factors, such as tested bacterial strains and different concentrations, as well as the main constituents of essential oils [57-59]. These results suggest that the relation between EO component and antibacterial activity may be due to their major constituents, such as dill apiole and anethole, which have aromatic nucleus containing polar functional group [60]. Moreover, our findings strengthen the consistency of the high MIC value found for dill seed oil, which is likely due to the presence of dill apiole and carvantonacetone components.

Based on the results of some previous studies, Sharopov et al. [46] screened dill herb oil against Bacillus cereus, Staphylococcus aureus, Pseudomonas aeruginosa, and Escherichia coli bacteria and Aspergillus niger fungi, but reported that the essential oil showed marginal antimicrobial activity only against Escherichia coli $\left(\mathrm{MIC}=625 \mu \mathrm{g} \mathrm{mL} \mathrm{m}^{-1}\right)$. Similarly, Arora and Kaur [61] reported that the aqueous extracts of dill showed broadspectrum antibacterial activity against Staphylococcus aureus, Escherichia coli, Pseudomonas aeruginosa, Salmonella typhimurium, Shigella flexneri and Salmonella typhi. However, dill seed oil showed activity at MIC (0.47, 0.37 and 0.17\%) for E. coli (ATCC 43895), S. aureus (ATCC 25923) and Saccharomyces cerevisiae, respectively, whereas no activity was observed against $S$. typhimurium, P. fragi DC7 and L. monocytogenes (LCDC 81-861) [62]. The extracts of dill leaf and seed were studied for antimicrobial activity with the agar well diffusion technique against $S$. aureus, E. coli and C. albicans. The leaf extracts showed no antibacterial activity, whereas the extract of dill seed exhibited the inhibition of C. albicans growth (19 mm. inhibition zone) [63].

The results of the current study related to antibacterial activities of dill are in agreement with those of Sharopov et al. [46], Arora and Kaur [61] and Rasheed et al. [63], but different antibacterial activities were reported by Delaquis et al. [62]. With regard to different environmental and genetic factors, the changes in antibacterial activity of dill essential oils may be related to the different chemical compositions of these oils and the use of FYM.

\section{Conclusion}

The findings of this study suggest that the FYM application has promising effects on dill, and this is in agreement with scarce research available in the literature concerning the effect of organic fertilizers on medicinal plants. According to our results, it can be concluded that the application of different doses of FYM is not only suitable for the essential content and components but it is also a way for increasing the antioxidant activity and antimicrobial activities of dill. The results also showed that the application of $15 \mathrm{t} \mathrm{ha}^{-1}$ FYM had a better effect on the dill essential oil content. Furthermore, $60 \mathrm{~kg} \mathrm{ha}^{-1} \mathrm{AN}$ infusion and $120 \mathrm{~kg} \mathrm{ha}^{-1}$ AN decoction, as well as $7.5 \mathrm{t}$ $\mathrm{ha}^{-1}$ FYM and $10 \mathrm{tha}^{-1}$ FYM essential oils were the most effective hydrogen and electron donors, containing the highest amounts of phenolic compounds; thus, dill herb can be considered as the best antioxidant.

In all FYM and AN fertilizer applications, DPPH methods showed the highest antioxidant activity among the all the studied methods. In general, there was a relatively consistent and positive correlation between the essential oils extracted from dill herb and seed in terms of antimicrobial features; however, the later showed particularly higher antimicrobial activity. Thus, this study confirms the bioactive potential of dill, and in addition to its use as food condiment and in pharmaceutical industries, the 
aqueous extracts of this plant can be utilized for antimicrobial and antioxidant purposes.

\begin{abstract}
Abbreviations
FYM: Farmyard manure; AN: Ammonium nitrate; DAP: Diammonium phosphate; $\mathrm{t} \mathrm{ha}^{-1}$ : Ton hectar ${ }^{-1}$; $\mathrm{kg} \mathrm{ha}^{-1}$ : Kilogram hectar ${ }^{-1}$; $\mathrm{d}$ : Day; GC-MS/FID: Gas Chromatography-Mass spectrometry/Flame ionization detection; DPPH: 1,1-Diphenyl-2-picrylhydrazyl; TRAP: Total radical antioxidant potential assay; TEAC: Trolox equivalent antioxidant coefficient; FRAP: Ferric reducing antioxidant power assay.
\end{abstract}

\section{Acknowledgements}

This study is part of a MSc Thesis and it was supported by Scientific Research Project Fund (2017.10.07.1205), Faculty of Agriculture, Bolu Abant Izzet Baysal University, Turkey.

\section{Authors' contributions}

$\mathrm{SO}, \mathrm{GY}$ and MC have contributed in the conceptualization and designing of the experiment, statistical analysis and manuscript preparation. SO, NO, GY and MC support to carry out the laboratory studies. All authors read and approved the final manuscript.

\section{Funding}

No research funding received.

Availability of data and materials

All available data are shown in tables.

\section{Declarations}

\section{Ethics approval and consent to participate}

Not applicable.

\section{Consent for publication}

The authors give their personal consent for publication.

\section{Competing interests}

The author declares that they have no competing interests.

\section{Author details}

${ }^{1}$ Department of Field Crops, Faculty of Agriculture, Bolu Abant Izzet Baysal University, 14280 Bolu, Turkey. ${ }^{2}$ Department of Biochemistry, Faculty of Pharmacy, Istanbul University, 34416 Istanbul, Turkey.

Received: 27 November 2020 Accepted: 19 March 2021

Published online: 21 April 2021

\section{References}

1. Sefidkon F. Essential oil composition of Anethum graveolens L. Pajouheshva-sazandegi. 2001;14:73-7.

2. Grosso C, Ferraro V, Figueiredo AC, Barroso JG, Coelho JA, Palavra AM. Supercritical carbon dioxide extraction of volatile oil from Italian coriander seeds. Food Chem. 2008;111:197-203.

3. Babri RA, Khokhar I, Mahmood Z, Mahmud S. Chemical composition and insecticidal activity of the essential oil of Anethum graveolens L. Sci Int (Lahore). 2012;24:453-5.

4. Sharafi S, Rasooli I, Owlia P, Taghizadeh M, Astaneh SD. Protective effects of bioactive phytochemicals from Mentha piperita with multiple health potentials. Pharmacogn Mag. 2010;6:147-53.

5. Choi KC, Son YO, Hwang JM, Kim BT, Chae M, Lee JC. Antioxidant, antiinflammatory and anti-septic potential of phenolic acids and flavonoid fractions isolated from Lolium multiflorum. Pharm Biol. 2017;55(1):611-9.

6. Foissy D, Vian JF, David C. Managing nutrient in organic farming system: relianceon livestock production for nutrient managementof arable farmland. Org Agric. 2013:3:183-99.
7. Sowiñska-Jurkiewicz A, Bryk M, Medvedev VV. Long-term organic fertilization effect on chernozem structure. Int Agrophys. 2013;27:81-7.

8. Nandapure SP, Imade SR, Mahajan RV, Jadhao SM, Wankhade SG. Uptake of micro nutrients by Java citronella as influenced by different treatments of nutrient management under inceptisols. Bull Environ Pharmacol Life Sci. 2017;6(3):371-7.

9. Melese W. Effect of farm yard manure application rate on yield and yield components of lettuce (Lactuca sativa) at Jimma Southwestern Ethiopia. Int J Res Granthaalayah. 2016:4(8):75-83.

10. Boru M, Tsadik Kebede W, Tana T. Effects of application of farmyard manure and inorganic phosphorus on tuberous root yield and yield related traits of sweet potato (Ipomoea batatas (L.) Lam) at Assosa Western Ethiopia. . Adv Crop Sci Tech. 2017;5(4):1-8.

11. Ng'etich OK, Aguyoh JN, Ogweno JO. Effects of composted farmyard manure on growth and yield of spider plant (Cleome gynandra). Int J Sci Nat. 2012;3(3):514-20.

12. Erdal İ, Küçükyumuk Z, Şimşek K, Basır M, Baysal GD. Effect of different animal manures on growth and mineral nutrition of tomato. Süleyman Demirel University Journal of the Faculty of Agriculture 1st International Agricultural Structures and Irrigation Congress. 2018(Special Issue):295-302.

13. Katar N. Effects of different nitrogen doses on yield and quality characteristics of summer savory (Satureja hortensis L.) Master of Science Thesis. Osmangazi University, Department of Field Crops. Eskişehir, Turkey. 2015.

14. Içen A. The effect of different nitrogenous doses on yield and quality characteristics of safflower (Carthamus tinctorius L.) Master of Science Thesis. Dicle University Department of Field Crop Institute of Natural and Applied Sciences. Diyarbakır, Turkey. 2019.

15. Katar D, Gürbüz B. The effect of different plant densities and nitrogen doses on drug leaf yield and some features of lemon balm (Melissa officinalis L.). J Agric Sci. 2008;14(1):78-81.

16. Koç $\mathrm{H}$. The effect of nitrogen fertilizations on the yield and quality of sage (Salvia officinalis L.). JAFAG. 2000;17(1):89-93.

17. Jana S, Shekhawat GS. Phytochemical analysis and antibacterial screening of in vivo and in vitro extracts of Indian medicinal herb: Anthum graveolens. Res J Med Plant. 2010;4:206-12.

18. Anonymous. Data of Bolu Directorate of Provincial Food Agriculture and Livestock. http://www.tarim.gov.tr. Accessed 29 Jan 2018.

19. Chandra K. Organic manures. In: Booklet released on the occasion of 10 days training programme on "Production and Quality Control of Organic Inputs" in Kottayam, Kerala. India: Regional Centre of Organic Farming; 2005.

20. Anonymous. Soil, Fertilizer and Water Resources Central Research Institute. Republic of Turkey Ministry of Agriculture and Forestry, Ankara. 2017.

21. Mata AT, Proença C, Ferreira AR, Serralheiro MLM, Nogueira JNF, Araújo MEM. Antioxidantand antiacetylcholinesterase activities of five plants used as Portuguese food spices. Food Chem. 2007;103:778-86.

22. SITARC. Bolu Abant İzzet Baysal University, Scientific Industrial and Technological Application and Research Center, https://betum.ibu.edu.tr/en/. Accessed 17 Jul 2018

23. Slinkard K, Singleton VL. Total phenol analyses: automation and comparison with manual methods. Am J Enol Viticul. 1977;28:49-55.

24. Brand-Williams W, Cuvelier ME, Berset C. Use of a free radical method to evaluate antioxidant activity. LWT Food Sci Tech. 1995;28:25-30.

25. Re R, Pellegrini N, Proteggente A, Pannala A, Yang M, Rice-Evans C. Antioxidant activity applying an improved ABTS Radical Cation Decolorization Assay. Free Radical Biol Med. 1999;26(9-10):1231-7.

26. Benzie IFF, Strain JJ. The Ferric Reducing Ability of Plasma (FRAP) as a measure of 'Antioxidant Power': the FRAP Assay. Anal Biochem. 1996:239:70-6

27. Nishikimi M, Rao NA, Yagi K. The occurrence of superoxide anion in the reaction of reduced phenazine methosulfate and molecular oxygen. Biochem Biophys Res Commun. 1972;46(2):849-54.

28. Yaldiz G, Camlica M, Ozen F. Biological value and chemical components of essential oils of sweet basil (Ocimum basilicum L.) grown with organic fertilization sources. J Sci Food Agric. 2019;99:2005-13.

29. Manhas SS, Gill BS. Effect of planting materials, mulch levels and farmyard manure on growth, yield and quality of turmeric (Curcuma longa). Indian J Agric Sci. 2010;80(6):501-6. 
30. Krüger H, Hammer K. A new chemotype of Anethum graveolens L. J Essent Oil Res. 1996;8:205-6.

31. Badoc A, Lamarti A. A chemotaxonomic evaluation of Anethum graveolens L. (dill) of various origins. J Essent Oil Res. 1991;3:269-78.

32. Stanojeviš LP, Raduloviš NS, Djokiš TM, Stankoviš BM, lliš DP, Cakiš MD, Nikoliš VD. The yield, composition and hydro distillation kinetics of the essential oil of dill seeds (Anethii fructus) obtained by different hydrodistillation techniques. Ind Crops Prod. 2015;65:429-36.

33. Said-Al Ahl H, Omer EA. Essentıal oil content and chemical composition of eight dill (Anethum graveolens L.) cultivars cultivated under Egyptian conditions. Int J Pharm Pharm Sci. 2016;8(5):227-31.

34. Tisserand R, Young R. Essential oil safety: a guide to health care professionals. London: Churchill Livingstone; 2014.

35. Razzaghi-Abyaneh M, Yoshinari T, Shams-Ghahfarokhi M, Rezaee MB, Nagasawa H, Sakuda S. Dillapiol and apiol as specific inhibitors of the biosynthesis of aflatoxin G1 in Aspergillus parasiticus. Biosci Biotechnol Biochem. 2007;71:2329-32.

36. Morcia C, Tumino G, Ghizzoni R, Terzi V. Carvone (Mentha spicata L) Oils. In: Essential oils in food preservation, flavor and safety. Elsevier; 2016, 309-316. https://doi.org/10.1016/B978-0-12-416641-7.00035-3

37. Pandey V, Patel A, Patra DD. Integrated nutrient regimes ameliorate crop productivity, nutritive value, antioxidant activity and volatiles in basil (Ocimum basilicum L.). Ind Crops Prod. 2016;87:124-31.

38. Pandey V, Patel A, Patra DD. Amelioration of mineral nutrition, productivity, antioxidant activity and aroma profile in marigold (Tagetes minuta L.) with organic and chemical fertilization. Ind Crops Prod. 2015;76:378-85.

39. Hussein AH, Said-Al A, Sarhan AM, Abou Dahab M, El-Shahat N, Zeid A, All MS, Naguib NY. Flavonoids, essential oil and its constituents of Anethum graveolens L. herb affected by nitrogen and bio-fertilizers. Agri Biol Sci J. 2015;1(3):105-9.

40. Ruangamnart A, Buranaphalin S, Temsiririrkkul R, Chuakul W, Pratuangdejkul J. Chemical compositions and antibacterial activity of essential oil from dill seeds (Anethum graveolens L.) cultivated in Thailand. Mahidol Univ J Pharm Sci. 2015;42(3):135-43.

41. Kazemi M. Phenolic profile, antioxidant capacity and anti-inflammatory activity of Anethum graveolens L. essential oil. Nat Prod Res. 2015;29(6):551-3.

42. Madandoust M, Fooladchang M. Effect of nitrogen fertilizer on essential oil content and its compositions in Anethum graveolens L. J Essent OilBear Plants. 2018:21(5):1266-71.

43. Darzi MT, Haj S, Hadi MR. Effects of the application of organic manure and biofertilizer on the seed yield and yield components in Dill (Anethum graveolens). J Med Plants Res . 2012;6(17):3345-50.

44. Jianu C, Misca C, Pop G, Rusu LC, Ardelean L, Lukinich-Gruia AT. Chemical composition and antimicrobial activity of essential oils obtained from dill (Anethum graveolens L.) grown in Western Romania. Rev Chim. 2012;63(6):641-5.

45. Singh G, Maurya S, De Lampasona MP, Catalan C. Chemical constituents, antimicrobial investigations, and antioxidative potentials of Anethum graveolens L. J Food Sci. 2005;70:208-15.

46. Sharopov SF, Wink M, Gulmurodov IS, Isupov SJ, Zhang H, Setzer WN. Composition and bioactivity of the essential oil of Anethum graveolens $\mathrm{L}$. from Tajikistan. Int J Med Aromatic Plants. 2013:3(2):125-30.

47. Albayrak S, Aksoy A, Sagdıc O, Albayrak S. Antioxidant and antimicrobıal activities of different extracts of some medicinal herbs consumed as tea and spices in Turkey. J Food Biochem. 2012;36:547-54.

48. Zheng W, Wang S. Antioxidant activity and phenolic composition in selected herbs. J Agric Food Chem. 2001;49:5165-70.

49. Sousa C, Pereira DM, Pereira JA, Bento A, Rodrigues MA, Dopico-García S, Valentão P, Lopes G, Ferreres F, Seabra RM, Andrade BA. Multivariate analysis of tronchuda cabbage (Brassica oleracea $\mathrm{L}$. var. costata DC) phenolics: influence of fertilizers. J Agric Food Chem. 2008:56:223-9.

50. Taie HAA, Salama ZAR, Radwan S. Potential activity of basil plants as a source of antioxidants and anticancer agents as affected by organic and bio-organic fertilization. Notulae Botanicae Horti Agrobotanici ClujNapoca. 2010:38:119-27.

51. Martins N, Barros L, Santos-Buelga C, Henriques M, Silva S, Ferreira Isabel CFR. Decoction, infusion and hydroalcoholic extract of Origanum vulgare L.: Different performances regarding bioactivity and phenolic compounds. Food Chem. 2014;158:73-80.
52. Nanasombat S, Teckchuen N. Antimicrobial, antioxidant and anticancer activities of Thai local vegetables. J Med Plants Res. 2009;3(5):443-9.

53. Al-Ismail KM, Aburjai T. Antioxidant activity of water and alcohol extracts of chamomile flowers, anise seeds and dill seeds. J Sci Food Agric. 2004;84(2):173-8.

54. Shyu YS, Lin JT, Chang YT, Chiang CJ, Yang DJ. Evaluation of antioxidant ability of ethanolic extract from dill (Anethum graveolens L.) flower. Food Chem. 2009;115:515-21.

55. Bozin B, Mimica-Dukic N, Simin N, Anackov G. Characterization of the volatile composition of essential oils of some Lamiaceae spices and the antimicrobial and antioxidant activities of the entire oils. J Agric Food Chem. 2006:54(5):1822-8.

56. Wortman SE, Galusha TD, Mason SC, Francis CA. Soil fertility and crop yields in long-term organic and conventional cropping systems in Eastern Nebraska. Renewable Agric Food Syst. 2012;27(3):200-16.

57. Bachir RG, Benali M. Antibacterial activity of the essential oils from the leaves of Eucalyptus globulus against Escherichia coli and Staphylococcus aureus. Asian Pac J Trop Biomed. 2012;2(9):739-42.

58. Kordali S, Kotan R, Mavi A, Cakir A, Ala A, Yildirim A. Determination of the chemical composition and antioxidant activity of the essential oil of Artemisia dracunculus and of the antifungal and antibacterial activities of Turkish Artemisia absinthium, A. dracunculus, Artemisia santonicum, and Artemisia spicigera essential oils. J Agric Food Chem. 2005;53(24):9452-8.

59. Kim J. Phytotoxic and antimicrobial activities and chemical analysis of leaf essential oil from Agastache rugosa. J Plant Biol . 2008;51(4):276-83.

60. Nazzaro F, Fratianni F, De Martino L, Coppola R, De Feo V. Effect of essential oils on pathogenic bacteria. Pharmacology. 2013;6:1451-74.

61. Arora DS, Kaur GJ. Antibacterial activity of some Indian medicinal plants. J Nat Med. 2007;61:313-7.

62. Delaquis PJ, Stanich K, Girard B, Mazza G. Antimicrobial activity of individual and mixed fractions of dill, cilantro, coriander and eucalyptus essential oils. Int J Food Microbiol. 2002;74:101-9.

63. Rasheed EM, Hamudi M, Kreem MR. Antimicrobial activity and the median lethal dose of dill (Anethum graveolens) extract. Diyala Agric Sci J . 2010;2(1):16-27.

\section{Publisher's Note}

Springer Nature remains neutral with regard to jurisdictional claims in published maps and institutional affiliations.

\section{Submit your manuscript to a SpringerOpen ${ }^{\odot}$ journal and benefit from:}

- Convenient online submission

- Rigorous peer review

- Open access: articles freely available online

- High visibility within the field

- Retaining the copyright to your article

Submit your next manuscript at $\boldsymbol{\nabla}$ springeropen.com 